\title{
Painting the Body: Feminist Musings on Visual Autographies
}

\author{
Maria Tamboukou, University of East London, UK
}

\begin{abstract}
In this paper I look at autographical depictions of the body in the work of Mato loannidou, a Greek woman artist, who participated in a wider narrative-based project on visual and textual entanglements between life and art. The paper unfolds in three parts: first, I give an overview of loannidou's artwork, making connections with significant events in her life; then I discuss feminist theorizations of embodiment and visual auto/biography; and finally I draw on insights from Spinozist feminist philosophers to discuss the artist's portrayal of women's bodies in three cycles of her work. What I argue is that the body becomes a centerpiece in the attempt to perceive connections between life and art through expressionism rather than representation.
\end{abstract}

My painting is all about my life, nothing else. . . . through my paintings I tell my life-story, I write my autobiography. . . . I have often painted raw feelings and emotions before I had even realized what I had been going through.

- Mato loannidou

The extract above comes from a life-history interview with the Greek artist Mato loannidou in her studio in Athens in May 2006, part of a wider project with contemporary women artists. ${ }^{1}$ In preparation for this interview, I had visited loannidou's solo exhibition ${ }^{2}$ in the Greek island of Syros in the summer of 2005, and I had also meticulously studied exhibition catalogs of her previous work. However, it was actually when I went to her studio for the interview that I had the chance to immerse myself in the rich and colorful world of her paintings across times and places. Ioannidou's artwork is rich and multifaceted, in terms of both themes and topics as well as the media and materials she is working with, ${ }^{3}$ but in this paper I will focus on her artistic and aesthetic practices vis-à-vis female bodies. What I argue is that loannidou's paintings are forcefully entangled with autobiographical narratives and create a plane for the female self to emerge as an embodied figure in the web of human and nonhuman relations. The essay unfolds in three parts: first I give an overview of loannidou's artwork, then I discuss feminist theorizations of embodiment in philosophy and visual auto/biography, and finally I make connections between insights from Spinozist feminist philosophers with loannidou's portrayal of women's bodies in three cycles of her work: Erotics, Women, and Ai-Giorgis (Saint George).

\section{Mato loannidou: A Self-Portrait of the Artist}

Mato loannidou was born in Athens in 1960 and studied French literature, theater, and painting at the Sorbonne and at the École des Beaux-Arts in Paris between 1978 and 1985. She then returned to Athens, where she has lived and worked as an independent artist but also as an art teacher in schools and community workshops. Talking about her journey, loannidou remembered that she had always wanted to become an artist, but the routes she followed to become one were not quite straightforward. After failing to enter the School of Fine Arts in Athens, she went to Paris, and it was while being absorbed in the literary worlds and the medieval phonetics of the French language that she became inspired to take up painting again. Her first maître was the sculptor Roger Plin, ${ }^{4}$ about whom she says, "I owe a lot"; when he retired, and after some anxious wanderings, she followed Jean Bertolle's atelier. ${ }^{5}$ What drew her to these ateliers was a disciplined approach to what art should be about, which was quite out of tune with the 1980s spirit of experimentation and of 
"anything goes." Ioannidou fondly remembered Plin as an art teacher of the old guard, who would show interest in his students but would also be sharply critical of their work. "He would look at our drawings and would say, 'No, Rodin would never do that, what are you doing?'” loannidou admits that such an approach was quite unpopular for many art students, "but for me it was exceptionally rich to be juxtaposed with Rodin. I didn't know about Camille Claudel then ..." she commented playfully during the interview. ${ }^{6}$

Upon her return to Athens, a city she had greatly missed, since she "never got excited with Paris," loannidou set up her studio in a flat near the Acropolis, where she is still based and where the interview was conducted. Her first solo exhibition in 1988 was a collection of seascapes and landscapes as well as interiors and urban scenes painted from the window of her atelier, "in the joy of the Greek light." 7 It was soon after this exhibition that "I fell in love," and from then on, "I started painting the Erotics," she told me at the interview. ${ }^{8}$ When I asked her about whether her life and artwork were intertwined, loannidou was bold and adamant, as we have already seen in the interview extract that opened this paper: "My painting is all about my life, nothing else. I have not found another reason to paint. For better or for worse, I can't do otherwise. I say it as I feel it. If I want to take a distance and theorize it, my life is the prime raison d'être of my painting, but beyond that, every time I experiment with modalities of expression, I unconsciously respond to things of concern that I am not necessarily aware of. . . My painting is of my times, a response to what is happening around me. . . I can tell you that through my paintings, I tell my life story, I write my autobiography."

In elaborating on the complex interrelationship between her art and her life, loannidou places her lived experiences at the heart of her artistic creativity, adding that her artistic expression preceded her cognitive understanding of complex relations with the world and with others: "First I paint something and it might take months or years to look back and understand how I felt at the time," she told me at the interview. This reciprocal relation between art and life was expressed in the two cycles of her Erotics, in 1990 and 1995 : "The first cycle of the Erotics were landscapes. Figures are still like shadows within spaces." Ioannidou thus sees her 1990 Erotics exhibition as a continuation of the 1988 landscapes and interiors: "the emergence of the figure is still indiscernible in these oeuvres." There was a feeling of incompleteness in this first cycle of the Erotics, which is why she went on working with this theme until 1995, when she had the second exhibition on the same theme. In her view, this second exhibition marked the point where "the encounter of bodies, as well as the energy they emitted in space" was exhausted, in her artwork but also in her life, as the turmoil of love came to devour her energy and creativity for a very long period: "I could not touch my brushes and I was not motivated whatsoever to paint."

loannidou went through dark times of total disillusionment, not only with her own work and motivation but also with the wider state of things in art at the time: "painting was torturing me and I did not want to have anything to do with it." Despite her disillusionment, she kept her studio, "which meant something." It was during these two years of artistic paralysis that she started doing some collage work with torn papers and other materials, which somehow expressed the chaos and fragmentation of her lived experiences, but which were also a sign of her flickering desire to reconstitute some sense of order and orientation: "this is why I have since thought that art took me out of this." Collage work was thus "the thread" that she took up again, supported by theoretical and auto/biographical readings, mostly artists' diaries and journals. When this short interim period of collage work ended, Women emerged as the overarching theme of her artwork: "With the Women, my own self-healing started. . . . these were broken women in dark backgrounds, they were essentially like rubber dummies, who could barely live or stand on their feet and they were definitely endangered. . . . I worked with this theme for many years, five maybe, and that's why the paintings evolve in phases; beyond those who melt away and are in the brink of existence, there were others who were leaping, crying, burning, setting themselves on fire, and in the last period there were the kourotrofoi and the kores, who start having bodily dimensions, take up a bit of space, feed and care for others."

loannidou had difficulties in finding gallery space for her Women, although she was reluctant to admit that it might have to do with the theme. What she vividly remembered is that the exhibition had a psychic influence on the spectators: "they were all leaving shaken." The time of the exhibition was an eventful one in her personal and professional life: apart from immersing herself passionately into painting again, she left her job as an art teacher in a prestigious private school in Athens. She separated from her lover and also founded the Leschi Artistic Workshops, a community art club at the heart of an ethnic minority area in Athens, which took up a lot of her energy, time, and creative work. ${ }^{9}$ Her next exhibition in 2003, a collection of bazaars and mermaids, ${ }^{10}$ was largely influenced by the Leschi Artistic Workshops activities and particularly by the street theater performances that she had directed until then. This time it was not just her personal life but the everyday life of her neighborhood that inspired her artwork: "This was an urban area that hosted the Muslim minority from Thrace [northern Greece], and it was like an island at the heart of the city with many children in the streets, not abandoned, but there were no boundaries between the house, the doorstep, and the street, 
and I somehow felt connected with this neighborhood. . . . It is not that I was not initially scared, but I eventually found it rich. So, as the Muslim people would organize wedding parties in the street and would block the traffic and nobody stopped them and there would be barbecues and life music. . . I had the idea of staging street theater performances for children."

It was in this colorful context of street theater, collective art workshops, and surrealist group writing that the figure of the Mermaid emerged in loannidou's artwork. As a mythical Greek female figure, the Mermaid cast a spell on her artistic imagination to the point that, she says, "I thought I was the Mermaid." There were many playful elements in this cycle of work, which blended with images from her childhood, when she would be happy being left alone to play with button boxes and other mundane materials that she would reassemble and experiment with: "I was happy because I had been given beads and I could play with them." Having seen this exhibition in Syros myself, I asked loannidou about the role of texts in this cycle of her work. She told me that apart from objects, she had also been collecting literary and folk stories about the Mermaid, some of which had found a place in her artwork. The autobiographical aspects of her artwork notwithstanding, she had never used her own texts in her work, since this would be very restrictive and would foreclose possibilities for whatever meaning her work might convey: "I am not interested in expressing myself through discourse. ... I I refuse to add textual commentaries on my work; it should speak for itself." Although refusing to write about her work, loannidou was open to dialogic exchanges between her visual art and literary production, specifically poetry. As the Mermaid cycle was coming full circle, the Ai-Giorgis (Saint George) series emerged. ${ }^{11}$ This artistic idea did not come out of the blue:

Ai-Giorgis was the answer to the Mermaid series, this is what I said without knowing why. . . . It was during this time that I happened to listen to a verse from Maria Topali, which excited me, did something to me, it gave birth to images and ideas:

I, St. George, shall free the all-beautiful one whom I hold captive in my guts,

I, the Dragon. ${ }^{12}$

I asked Maria Topali, "Who is St. George?" and she told me "Saint George is me" . . so later in my paintings the all-beautiful one was Saint George. ..."

The Ai-Giorgis series - some pieces of which were also exhibited in London at an exhibition I curated for the women artists who had participated in my project (Tamboukou, "Becomings")-initiated a cycle of paintings by loannidou wherein male, female, monster, and animal bodies are entangled and intertwined. It was through blending colors, lines, symbols, and figures that sex, gender, and human and nonhuman borders were traversed and reconfigured. The artist identified herself with St. George: "I was Ai-Giorgis," she told me, but also "the all-beautiful one" becomes Ai-Giorgis in loannidou's artistic imagination. It is this explosion of human and nonhuman bodies in the artistic and auto/biographical imagination that I want to consider in the next section. In doing so, I will look at feminist theorizations of the body, and I will explore ways of seeing and understanding embodied depictions in textual and visual autographical narratives.

\section{Corporeal Feminisms and Visual Autographies}

Feminist theorists have long interrogated philosophical representations of human embodiment. ${ }^{13}$ They have particularly grappled with the problem of how to theorize embodiment, considering the corporeality of the human condition as well as its multiple material, social, cultural, and sexual differences. Visual theoristsfeminists among them - have further been concerned with the difficulty of representing the diversity of bodies through language, images, and discourse, and they have radically interrogated representation as a concept. ${ }^{14}$ The literature is vast and ever growing, but for the purpose of this essay, I will focus on Spinozist feminists and their critique of poststructuralist approaches to the body.

Judith Butler's work, and particularly her argument that bodies are always already effects of discursive formations, was pathbreaking in interrogating the sex-gender distinction (Butler, Bodies that matter). While undoing this distinction, however, Butler's work intensified the matter-representation dichotomy, as Claire Colebrook has argued ("From" 77). In Colebrook's analysis, it was the Australian philosophers Genevieve Lloyd, Moira Gatens, and Elizabeth Grosz who used corporeality "as a means of deconstructing [the] sameness/difference opposition" (76), mostly influenced by Spinoza and Deleuze."15

Gatens's work has been highly influential in the field of corporeal feminisms, and her notion of "imaginary bodies" has inspired new ways of interrogating discourses around and about the body. In explicating her use of the notion, Gatens has clarified that "an imaginary body is not simply a product of subjective imagination, fantasy or folklore" (Imaginary viii). It is rather used to denote "the (often 
unconscious) imaginaries of a specific culture: those ready-made images and symbols through which we make sense of social bodies" (viii). Gatens's idea of "imaginary bodies," therefore, has been at the heart of how I have tried to understand artistic depictions of the female body in loannidou's paintings. Here, I have been particularly captivated by Gatens's strong Spinozistic influences in how she understands bodies, imagination, and expression: "Drawing upon Deleuze's readings of Spinoza, I have used Spinoza's notion of imagination in order to develop a notion of embodiment that posits multiple and historically specific social imaginaries" (Gatens, Imaginary $\mathrm{x}$ ). What has also drawn Gatens to Spinoza is his take on imagination and his insistence to keep it as an important component of the philosophical analysis, succinctly encapsulated in the first proposition of the fourth part of the Ethics: "Nothing positive which a false idea has is removed by the presence of the true insofar as it is true" (E IVP1). ${ }^{16}$

As Gatens has noted, Spinozistic approaches to the theorization of the body have been largely neglected in Anglo-American philosophy, although there has recently been an important wave of thinkers who have turned to Spinoza's ideas and writings for inspiration in the area of bodies, body politics, and beyond. ${ }^{17}$ Although biology and natural sciences have radically changed and advanced since Spinoza's times, his monistic philosophy has opened up ways to transcend dualisms that have dominated social and political thought in modernity, the mind-body distinction being one of them. As Gatens succinctly puts it, "for Spinoza the body is not part of passive nature ruled over by an active mind but rather the body is the ground of human action" (Imaginary 57). Since "the mind is the idea of the body"18 in Spinoza's universe, there is an ongoing body-mind interaction, a process through which neither the body nor the mind can be frozen or stabilized as substances; they are rather becomings in a neverending process of transformation. Lloyd has responded to Spinoza's proposition, arguing that "the body is not the underlying cause of the mind's awareness and knowledge, but rather the mind's object-what it knows. And the mind knows itself only through reflection on its ideas of body. Its nature is to be the idea of a particular body" ("Woman" 20).

It is through this mind-body assemblage that reason is not a force that submits the body to the orders and control of the mind. As Sarah Donovan has noted, "the mind is constituted by the affirmation of the actual existence of the body, and reason is active and embodied, precisely because it is the affirmation of a particular bodily existence" (179). Perceived beyond the mind-body dichotomy, reason thus emerges in its splendid materiality and situatedness. Once we have moved beyond the mind-body split and we have established "that the mind and the body are one and the same thing [and] that the order of actions and passions of the mind is, by nature, at one with the order of actions and passions of the mind" (E IIIP2S), then we can understand Spinoza's beautiful scholium in the third part of the Ethics that "no one has yet determined what the body can do" (E IIIP2S). Deleuze has particularly drawn on this passage to argue that this scholium is Spinoza's "cry" about what ethics should be about: "The point of view of an ethics is: of what are you capable, what can you do? Hence a return to this sort of cry of Spinoza's: what can a body do? We never know in advance what a body can do. We never know how we're organized and how the modes of existence are enveloped in somebody" ("Cours").

In Deleuze's reading of Spinoza's thought as expressionism in philosophy, the structure (fabrica) of a body and its potential for action cannot be separated: "what a body can do corresponds to the nature and limits of its capacity to be affected" (Expressionism 218). It is within this Spinozist-Deleuzian ontology that the body is not a ground, a being, or a substance but a modality of expression. As Lloyd has commented, we can grasp the notion of "expression" in Deleuze through the metaphors of the mirror and the seed: "Spinoza's attributes are mirrors, each expressing in its own way the essence of substances. But what is 'expressed' is also enveloped in the expression, like the tree in the seed" (Spinoza 31). This idea of expressionism in philosophyand particularly its readings in corporeal feminisms - has been catalytic in the way I have seen loannidou's autographical depictions of the body, as I will discuss in the next section.

But how is the body seen in the light of feminist approaches to visual autographies? In using the notion of "autography," I have drawn on Domna Stanton's important work, The Female Autograph, wherein she has bracketed "bio," that is life, from autobiographical theorizing. She did that not to deny that there is a "real" life out there but to foreground the problematic relationship between lived experiences and their representation, be it textual or visual. Stanton's insights have opened a line of feminist theorization of the autographical subject, which I have traced, followed, and indeed bended in my own work with textual and visual narratives of the female self. ${ }^{19}$ How we see, sense, interpret, and textualize art and how we bring together texts and images are pertinent questions around which a rich body of literature and a range of quite different approaches has evolved. ${ }^{20}$

In thus exploring the body in the context of visual autographies, I have deployed a mode of seeing, very much drawing on Deleuze's take on paintings developed in his work on Bacon and in his coauthored text with Felix Guattari, A Thousand Plateaus (Tamboukou, "Beyond"). There are two main themes that I have 
found particularly interesting for my own experiment in seeing: the concept of "faciality" and the problem of "painting forces." Ronald Bogue has pithily noted that Deleuze sees the human face "as an important constituent of every social configuration of language practices and power relations" (5). Deleuze has theorized the task of painting as "the attempt to render visible forces that are not themselves visible" (Francis 56). "Dismantling the face" and "capturing forces" have therefore become central axes in my analytical strategies of loannidou's autographical paintings.

While working in the fold of life and art, however, I have always been aware of the problem that Griselda Pollock has so succinctly identified and criticized, namely the auto/biographical lens that women artists' work has often been viewed through, as opposed to "the universal principles" that male artists' work is often assumed to address even when their work is discussed in relation to their life (Differencing 106). In tackling the problem of what I have called the "autobiographication" of women's art (Tamboukou, In the Fold 9), it is not the "bio" but rather loannidou's art as an autographic practice that I have focused on - that is, the multiplicity of ways she constitutes and indeed makes sense of herself as an artist through her art. As beautifully expressed in her interview, through painting she was expressing affects, emotions, and feelings, well before she had become aware of them.

In this context, it is not loannidou's "real life" events that I have been interested in, then, but "the logic of sense" (Deleuze, Logic) and indeed "the logic of sensation" (Deleuze, Francis) that allow autographical images and embodied figures to emerge from her paintings as "two sides of a certain folding" (Colebrook, "Grammar" 128), the folding between life and art. Pointing to the relation between philosophy and art in Deleuze and Guattari's thought, Colebrook has noted that "whereas philosophers create concepts that lead thought to the plane of pure difference from which intensities emerge, artists present us with those intensities" (Understanding 176). What I therefore argue is that loannidou's paintings create planes of intensities for singularities to emerge and forces to be released. In charting these intensities and forces, I have drawn upon her artwork as well as her life story to create an assemblage of visual and textual images of embodiment. It is thus to loannidou's artwork that I now turn, particularly focusing on her pictorial approaches to the body in three cycles of her work, The Erotics, Women, and Ai-Giorgis (Saint George).

\section{Painting What a Body Can Do}

Although as we have seen in the first section, loannidou locates the emergence of the erotics theme in the landscapes and interiors she painted upon her return to Athens in 1985, bodies emerge in her paintings through her first cycle of the Erotics, created between 1987 and 1990 . Her first exhibition in 1990 was a continuation of her landscapes series and comprised small-scale paintings, where body figures are indiscernible and entangled, saturated by mostly red, blue, and greenish backgrounds. ${ }^{21}$ The artist was still uncertain about the role of these figures in her paintings, and so she went on with the Erotics series until 1995, the date of her second exhibition. Her colors became darker in this second series, with mostly brown and grey hues; the paintings became bigger, while the bodies got even more entangled and indiscernible, gradually losing their sex and gender markers that were more readily identified in the first series. This second series is stronger in painting bodies that emit energy and intensities of pleasure and pain. ${ }^{22}$ It was the possibility of bodies to affect and to be affected that the artist was interested in, "the ferment of bodies," as she put it in her interview.

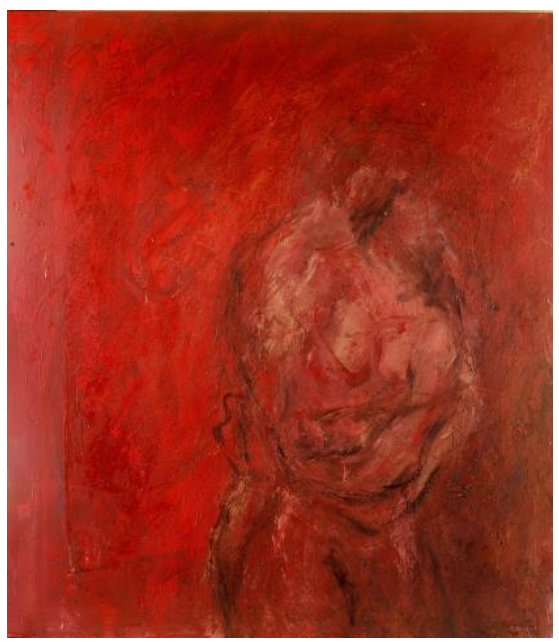

Figure 1: Erotics, oil on canvas 100x114

"I shall consider human actions and appetites just as if it were a question of lines, planes and bodies," wrote Spinoza in the third part of the Ethics (E, III). As Deleuze has pointed out, Spinoza defines beings "by their capacity for being affected by the affections of which they are capable, the excitations to which they react, those by which they are unaffected, and those which exceed their capacity and make them ill or cause them to die" (Spinoza 127). The more bodies become aware of their capacity to act the more joyful they become. Joy (laetitia) in Spinoza's philosophy is a primary affect, tightly 
interwoven with the crucial concept of conatus, the desire to persevere in our existence, as the essence of all beings-humans and nonhumans. Sadness (tristia) comes with the gradual realization that we lose the power to affect and be affected, and this capacity to act rather than be acted on "is an expression of one's freedom, power, virtue or conatus," Gatens has pithily noted ("Politics" 199). Thus bodies do not act in isolation; their power to act, to affect, and to be affected is always relational. It is in this light that embodiment in Spinoza's thought is not about individual bodies but about "their total milieu" (Gatens, "Politics" 201).

It is precisely the "total milieu" of embodied encounters that loannidou's Erotics forcefully express, visualizing the "lines, planes and bodies" that Spinoza refers to, in defining "human actions and appetites," as we have seen above. In painting lines, planes, and bodies, loannidou's artistic practices dismantle the faces of the lovers, rendering them indiscernible and insignificant. It is the encounter of the bodies, their movement in space, and the energy they emit that the artist is interested in as she tries to make sense of Eros's effects upon her own constitution as a woman in love: "the question for my art has always been how you can freeze in a pictorial image the sensation of some boiling material, which is most probably me." I was particularly attracted to loannidou's idea of creating images of Eros as an assemblage of corporeal forces. As I have argued elsewhere in my work, love is often conceptualized as passion in philosophical histories, while "women in love" is a topic often invoking passivity and submission or hysteria and madness (Tamboukou, Nomadic). Ioannidou's Erotics visualize the embodied link between Eros, desire, and movement and bring the body at the heart of visually capturing love as force.

But, as Deleuze has commented above on Spinoza's ontology, there are forces that exceed the capacity of bodies and may "make them ill or cause them to die." It is such a destructive period that loannidou went through in her life and work, temporarily defeated by the erotic forces she had celebrated in her paintings: "this great love almost destroyed me . . . and I started doubting the whole idea of painting, as a mode of expression." It is after this dark period that Women emerged as a forceful topic in her art, as we have already seen in the first section. Painting became for loannidou a mode of experimentation: it was through colors, lines, and embodied planes that she expressed forces of "becoming other." There are several striking motifs in this autographical series of female body paintings that I want to discuss in the light of Spinoza's philosophical insights around the unpredictability of "what a body can do": 1) bodies that fold and unfold, thus blurring distinctions between inner and outer boundaries; 2) bodies that hang in space with no orientation or association; 3) bodies that move and dance anxiously, leaping or falling; 4) body lines that become curves at the end of the cycle; and 5) embodied encounters in caring relations that put forward the figure of the wet nurse-not the mother. ${ }^{23}$ As Susan Langer has shown, "motifs are organized devices that give the artist's imagination a start. ... they guide it forward and guide its progress" (Feeling 69).

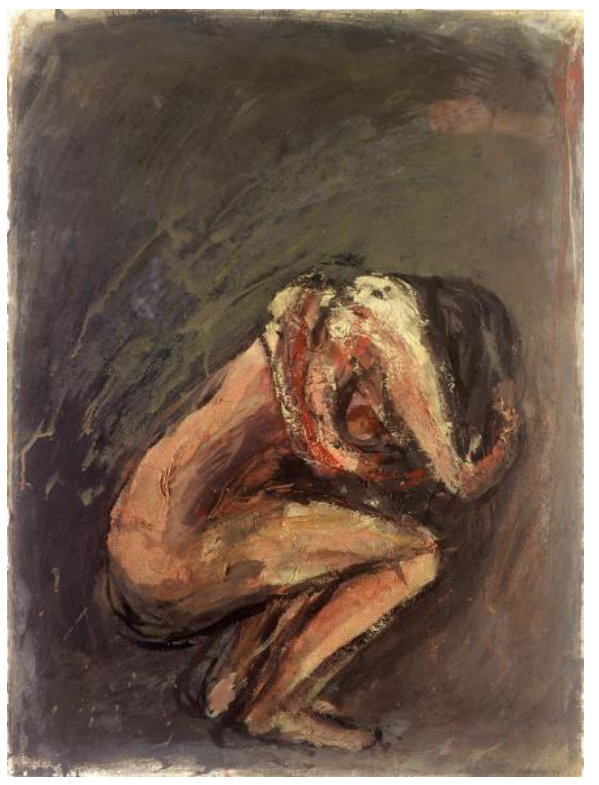

Figure 2: Women-Mato loannidou, acrylic on paper, 55x75, 1996

Deleuze has used Leibniz's concept of "the fold" to trace connections between spaces and bodies: the world folds into the self in different speeds and on a variety of levels and intensities, affecting the ways we live, relate to other bodies, and make sense of our worldliness (Deleuze, Fold). At the same time, however, we keep folding out into the world, as Foucault in his later work argued, acting upon received knowledge, discourses, and practices and thus molding ourselves as subjects through the deployment of "technologies of the self" (Foucault, "Technologies of the Self"). Elspeth Probyn has particularly pointed to the crucial concept of "the fold" in both Foucault's and Deleuze's analyses, foregrounding the very constitution of subjectivity as an incessant process of folding and unfolding: "The act of pleating or folding ('la pliure') is thus the doubling-up, the refolding, the bending-onto-itself of the line of the outside in order to constitute the inside/outside - the modes of the self" (129). In this light, the artist's erotic experiences fold into her body, activating a series of movements, thoughts, affects, and eventually pictorial practices that render embodied forces visible through processes of symbolic transformation. This was most influentially theorized by Langer, who took symbols as the expression of 
relations between material components and entities. Symbols are always material, she argued, looking closely at the minutiae, processes, and details of their transformation into words, propositions, and artwork (Philosophy 34).

In this context, bodies hanging in space are pictorial symbols of the artist's feelings of creative paralysis, of having lost the desire to paint, of having surrendered herself to the black holes and destructive forces of Eros, as recounted in her interview. "A work of art is often a spontaneous expression of feeling, i.e., a symptom of the artist's state of mind," Langer has noted (Feeling 25). Ioannidou has clearly admitted in her interview that in the beginning of her Women series their bodies expressed this feeling between existence and nonexistence, the ambiguity of art's and life's worth in their interrelation. In this sense, her female bodies hanging in space have become "significant forms," a concept introduced by art critic Clive Bell to denote "lines and colors combined in a particular way, certain forms and relations of forms, [that] stir our aesthetic emotions" (8). Bell coined this concept to articulate the idea that even when artworks cannot be linked to a recognizable context, they can still be expressive through their "significant form" as "the one quality common to all works of visual art" (8). Female bodies frozen in different positions of motion and rest thus became "significant forms," expressing the artist's feelings but also stirring the viewers' affects and imagination, although on different levels and in different times. While for loannidou Women expressed her emergence from the black hole of non-creativity, viewers would be thrown into the darkness the artist had escaped from; "they would leave shaken by the slaughtered women," as loannidou puts it.

It is precisely the artist's escape that the bodies' movement and dance would ultimately express: "in art forms are abstracted only to be made clearly apparent, and are freed from their common use only to be put to new uses: to act as symbols, to become expressive of human feeling," Langer has aptly commented (Feeling 51). Female bodies in loannidou's Women fly down from high above and move through disjointed articulations. Yet in their free-falling movement, they reassemble the artist's conatus, her will to persevere: while they throw light to what has come to ruin, they also point to new possibilities and potentialities-one can never know what a woman's body can do. As women's bodies move against destruction and erasure, they gradually take up space and expand. It is through this ongoing process that "transpositions" occur: lines turn into embodied curves, and the female figure, on the brink of extinction, becomes a source of life and care.

In Rosi Braidotti's theorization, transpositions is a concept drawn from both music and genetics indicating "an intertextual, cross-boundary or transversal transfer, in the sense of a leap from one code, field or axis into another, not merely in the quantitative mode of plural multiplications, but rather in the qualitative sense of complex multiplicities" (Transpositions 5). The artist holds her lines and curves together as a variation on the theme of how it feels to be a woman. There are changes, ruptures, and shifts, but also an overall harmonious pattern, while "central to transpositions is the notion of material embodiment" expressed through a spatial rhythm of forms, intersecting planes, shadows, and lights; in short, the artist's pictorial techniques. For Henri Matisse, expression is not about "the passion that will burst upon a face or will be asserted by a violent movement" (237), It is rather the overall arrangement of the "virtual space" of the picture that becomes a plane for embodied forces to become visible. As Langer has noted, we should not conflate the space we live and experience with "the virtual space" of the picture, which is created by means of color and "exists for vision alone" (Feeling 72). Interestingly enough, the curved figures are not "mothers" but kourotrofoi, women who feed and nurture in the tradition of neolithic figurines. Although loannidou's late Women are depicted as carers, they do not necessarily become mothers, an essentialist trap that the artist carefully avoids.

It was this artistic commitment to "transpositions" that was taken forward to the Ai-Giorgis (Saint George) series. As we have already seen in the first section, the inspiration for these paintings was a verse from a poem wherein Saint George pledges to free "the all-beautiful one" from the dragon. But the figures of the poetess, the artist, Saint George, the dragon, and "the all-beautiful one" are blended in this series of paintings. Replete with embodied encounters between monsters, women, animals, and mythical figures, the Ai-Giorgis series is a cartography of metamorphoses, transpositions, and becomings par excellence. As Braidotti has suggested, becoming is "a collective assemblage of forces that coalesce around commonly shared elements and empower them to grow and to last" (Metamorphoses 135). The Ai-Giorgis series thus becomes an assemblage where humans, animals, and monsters join forces, and in doing so they get entangled in a plane of immanence, where bodily differences become indiscernible. This process of becoming is saturated by desires and affects and thus explodes conventions of visual and textual representations. "The all-beautiful one" becomes Saint George, trying to kill the dragon, who lives within her viscera. The face of "the all-beautiful one" returns powerful in this series. Moreover, the mythical figure of Saint George brings in more religious myths in loannidou's paintings, most notably Eve and the serpent as the visual motif of "the cursed women," as loannidou told me in the interview. In creating this series of paintings, loannidou was inspired by a wide 
range of motifs, colors, and techniques from religious and popular art, radically disrupting their conventions through the female nude and the female face in countless repetitions and renditions. ${ }^{24}$ The fusion and blending of bodies is strikingly visible in this series, since "the encounter of two bodies bring something more than the two bodies together," as she told me at the interview.

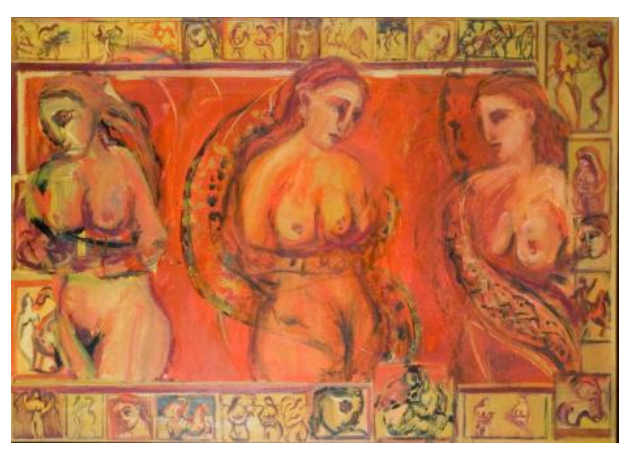

Figure 3: Saint George, Mato loannidou, 70x100, oil on canvas, 2007 paintings, among others. Rather, loannidou's series remains close to the social and cultural practices that created conditions of possibility for the artist to reimagine the female figure within religious and cultural myths that had initially marginalized and excluded her. The body of "the all-beautiful one" is clearly crucial in this process, wherein the imaginary functions as "a symbolic glue between the social and the self, the outside and the subject; the material and the ethereal" (143). Through the human, animal, and monster figures that blend and intra-act in the pictorial space, the artist blurs boundaries between actions and passions, reason and imagination, body and mind. Ai-Giorgis thus visualizes a plane of intensities as a Spinozistic way of living with intensities, and in doing so it increases one's reasonable understanding and intuitive knowledge and therefore freedom. The depiction of "the all-beautiful one" riding her horse and slaying the dragon in her guts is one of the most powerful symbols of becoming free. The idea of becoming rather than being free comes from Deleuze's reading of Spinoza: "man is not born free, but becomes free or frees himself" (Spinoza 70). It is this process of becoming free through action that loannidou's artwork has visually expressed.

\section{Embodied Cartographies of Feelings}

In this paper, I have looked at entanglements between life and art in a woman artist's paintings. Throughout her life-history interview, loannidou expressed in no uncertain terms that her art was all about her life, but the autobiographical components of her artistic compositions cannot be subsumed under any regime of representation-based ways of thinking, not in terms of mediating "the real self of the artist." Her artwork has thus been seen and discussed in the light of expressionism, a line of thinking that Deleuze has traced back to Spinoza's philosophy. In this light, loannidou's pictorial images have expressed feelings, affects, impressions, and desires as responses to "the real" rather than representations of it. The artist's response to the concerns, problems, and questions of "real life" in general and her own self in particular has the body at its heart. Indeed, the body has become the central piece of loannidou's artwork. It has created a material unity for the artist's imaginaries to unfold through lines, colors, planes, and forms expressed in a sequence of cycles in her artwork.

Presented and discussed as a series rather than single works of art, loannidou's paintings chart planes of lived experiences in terms of resolving space-time tensions and creating visual rhythms, eventually becoming embodied cartographies of affects, emotions, and feelings. As Langer has noted, it is not pure sensation that creates unity and meaning in human life but rather "sensation remembered and anticipated, feared or sought or even imagined and eschewed . . . by virtue of our thought and imagination we have not only feelings, but a life of feeling" (Feeling 372). It is thus "lives of feelings" that loannidou's paintings express through a variety of pictorial techniques and aesthetic practices that revolve around the female body, perceived within different sociocultural encounters, regimes, and imaginaries. 


\section{Acknowledgement}

I want to thank Mato loannidou for generously sharing her life story and for giving me permission to include images of her beautiful paintings in this article.

\section{Notes}

${ }^{1}$ For an overview of this project, see Tamboukou, "In the Fold."

2 The exhibition that I saw in Syros in 2005 had also been curated in Athens in 2003. For an overview, see loannidou, "Astra."

${ }^{3}$ For an overview of her work, see loannidou, Homepage.

${ }^{4}$ For more information on Plin, see Plin.

${ }^{5}$ For more information on Bertholle, see Bertholle.

${ }^{6}$ Camille Claudel was a French sculptor who worked with Rodin but also had a volatile relationship with him.

${ }^{7}$ For an overview of this exhibition, see loannidou, "Third."

${ }^{8}$ For an overview of these two exhibitions, see loannidou, "Adyto"; and "3."

9 For an overview of her work, see loannidou, "Leschi."

${ }^{10}$ Also, as noted above, see loannidou, "Astra."

${ }^{11}$ See loannidou, "Adam."

12 Verse translated by Alexandra Halkias. See Topali.

${ }^{13}$ For an overview of this body of literature, see Gonzalez-Arnal et al.; and Price and Shildrick.

${ }^{14}$ See, among others, Davis, et al.; Fleetwood; Jones; Mirzoeff; and Rice.

${ }^{15}$ For an overview of feminists' encounters with Deleuze, see Buchanan and Colebrook; and Nigianni and Storr.

${ }^{16}$ Abbreviated references to the Ethics follow the conventions introduced by Curley in the introduction to A Spinoza Reader (xxxv). Thus: $\mathrm{E}=$ Ethics, $\mathrm{P}=$ Proposition, $\mathrm{S}=\mathrm{Sch}$ lium

17 See Gatens, ed. for a comprehensive overview of this field.

18 " $[T]$ he object of the idea constituting the human mind is the body. Or a certain mode of extension which actually exists, and nothing else" (E IIP13).

${ }^{19}$ See Gilmore; Perrault; and Tamboukou, "Relational."

${ }^{20}$ See, among others, Brophy and Hladki; Gingell and Roy; Pollock, Vision; Riessman-Kohler; Rose; Smith and Watson; and Tamboukou, "Narrative."

${ }^{21}$ For more information, see "Adyto."

${ }^{22}$ For more information, see "3."

${ }^{23}$ For more information, see "Women."

${ }^{24}$ For more information, see "Adam."

\section{Works Cited}

Bell, Clive. Art. New York: F. A. Stokes, 1913. Print.

Jean Bertholle. Wikipedia, n.d. Web. 8 Feb. 2018.

Bogue, Ronald. Deleuze on Music, Painting and the Arts. London: Routledge, 2003. Print.

Braidotti, Rosi. Metamorphoses: Towards a Materialist Theory of Becoming. Cambridge: Polity, 2002. Print.

-. Transpositions: On Nomadic Ethics. Cambridge: Polity, 2006. Print.

Brophy, Sarah, and Janice Hladki, eds. Embodied Politics in Visual Autobiography. Toronto: U of Toronto P, 2014. Print.

Buchanan, Ian, and Claire Colebrook, eds. Deleuze and Feminist Theory. Edinburgh: Edinburgh UP, 2000. Print.

Butler, Judith. Bodies That Matter: On The Discursive Limits of Sex. London: Routledge, 1993. Print.

Colebrook, Claire. "From Radical Representations to Corporeal Becomings: The Feminist Philosophy of Lloyd, Grosz and Gatens." Hypatia 15.2 (2000): 76-93. Print.

-. "A Grammar of Becoming: Strategy, Subjectivism and Style." Becomings: Explorations in Time, Memory, and Futures. Ed. Elizabeth Grosz. Ithaca: Cornell UP, 1999. 117-40. Print.

-. Understanding Deleuze. Crows Nest, NSW: Allen \& Unwin, 2002. Print.

Curley, Edwin, ed. and trans. A Spinoza Reader: The Ethics and Other Works: Benedict de Spinoza. Princeton: Princeton UP, 1994. Print.

Davis, Rocío, et al., eds. Aesthetic Practices and Politics in Media, Music, and Art: Performing Migration. London: Routledge, 2011. Print.

Deleuze, Gilles. Expressionism in Philosophy: Spinoza. Trans. Martin Joughin. New York: Zone, 1992. Print.

-. The Fold: Leibniz and the Baroque. Trans. T. Conley. Minneapolis: U of Minnesota P, 1993. Print.

-. Francis Bacon: The Logic of Sensation. Trans. Daniel W. Smith. 1981. London: Continuum, 2003. Print.

—. "Cours Vincennes: Ontologie/Ethique, 21 Dec. 1980." Les Cours de Gille Deleuze. Webdeleuze, 2017. 8 Feb. 2018.

-. The Logic of Sense. Trans. Mark Lester. 1969. London: Continuum, 2001. Print.

-. Spinoza: Practical Philosophy. Trans. Robert Hurley. San Francisco: City Lights, 1988. Print.

Deleuze, Gilles, and Felix Guattari. A Thousand Plateaus: Capitalism and Schizophrenia. Trans. Brian Massumi. 1980. London: Athlone, 1988. Print.

Donovan, Sarah. “Rereading Irigaray's Spinoza." Gatens, ed. 165-87.

Fleetwood, Nicole R. Troubling Visions: Performance, Visuality, and Blackness. Chicago: U of Chicago P, 2010. Print.

Foucault, Michel. "Technologies of the Self". Technologies of the Self. Eds. Luther, H. Martin, Huck, Gutman, Patrick, H. Hutton. London: Tavistock. 16-49. Print. 
Gatens, Moira. Imaginary Bodies: Ethics, Power and Corporeality. London: Routledge, 1996. Print.

—. "The Politics of the Imagination." Feminist Interpretations of Benedict Spinoza. Ed. Gatens. University Park: Pennsylvania State UP. 189209. Print.

Gatens, Moira, ed. Feminist Interpretations of Benedict Spinoza. London: Routledge, 2009. Print.

Gilmore, Leigh. Autobiographics: A Feminist Theory of Women's Self-Representation. Ithaca: Cornell UP, 1994. Print.

Gingell, Susan, and Wendy Roy, eds. Listening Up, Writing Down, and Looking Beyond: Interfaces of the Oral, Written, and Visual. Waterloo: Wilfred Laurier UP, 2012. Print.

Gonzalez-Arnal, Stella, et al., eds. Embodied Selves. London: Palgrave. 2012. Print.

Grosz, Elizabeth. Volatile Bodies: Toward a Corporeal Feminism. Bloomington: Indiana UP, 1994. Print.

loannidou, Mato. “3 1995." Mato loannidou. Web. 8 Feb. 2018.

—. "Adam 2008." Mato loannidou. Web. 8 Feb. 2018.

—. "Adyto 1990." Mato loannidou. Web. 8 Feb. 2018.

—. "Astra 2003." Mato loannidou. Web. 8 Feb. 2018.

-. Homepage. Mato loannidou. Web. 8 Feb. 2018.

—. "Leschi." Mato loannidou. Web. 8 Feb. 2018.

-. Personal interview. 15 May 2006.

—. "Third [To trito mati 1988]." Mato loannidou. Web. 8 Feb. 2018.

—. "Women 2001." Mato loannidou. Web. 8 Feb. 2018.

Jones, Amelia. “Material Traces: Performativity, Artistic 'Work,' and New Concepts of Agency." TDR: The Drama Review 4 (2015): $18-35$. Print.

Langer, Susanne K. Feeling and Form. London: Routledge \& Kegan Paul, 1953. Print.

-. Philosophy in a New Key: A Study in the Symbolism of Reason, Rite and Art. 1942. New York: Mentor Books, 1951. Print.

Lloyd, Genevieve. Spinoza and the Ethics. London: Routledge, 1996. Print.

—. "Woman as Other: Sex, Gender, and Subjectivity." Australian Feminist Studies 10.4 (1989): 13-22. Print.

Matisse, Henri. “Notes d'un Peintre, 1908." Matisse on Art. Ed. Jack D. Flam. Berkeley: U of California P, 1995. 237-49. Print.

Mirzoeff, Nicholas. The Right to Look: A Counterhistory of Visuality. Durham: Duke UP, 2011. Print.

Nigianni, Chrysanthi, and Merl Storr, eds. Deleuze and Queer Theory. Edinburgh: Edinburgh UP, 2009. Print.

Perrault, Jeanne. Writing Selves: Contemporary Feminist Autography. Minneapolis: U of Minnesota P, 1995. Print.

Roger Plin. Wikipedia, n.d. Web. 8 Feb. 2018.

Pollock, Griselda. Differencing the Canon: Feminist Desire and the Writing of Art's Histories. London: Routledge, 1999. Print.

-. Vision and Difference: Femininity, Feminism and the Histories of Art. London: Routledge, 1988. Print.

Price, Janet, and Shildrick, Margrit, eds. Feminist Theory and The Body: A Reader, Edinburgh: Edinburgh UP, 1999. Print.

Probyn, Elspeth. Sexing the Self: Gendered Positions in Cultural Studies. London: Routledge, 1993. Print.

Rice, Carla. Becoming Women: The Embodied Self in Image Culture. Toronto: Toronto UP, 2017. Print.

Riessman-Kohler, Catherine. Narrative Methods for the Human Sciences. London: Sage, 2007. Print.

Rose, Gillian. Visual Methodologies: An Introduction to the Interpretation of Visual Materials. 2001. London: Sage, 2008. Print.

Smith, Sidonie, and Julia Watson, eds. Interfaces: Women, Autobiography, Image, Performance. Hawaii: U of Hawai'i P, 2002. Print

Spinoza, Baruch. Ethics. Ed. Seymour Feldman. Trans. Samuel Shirley. Indianapolis: Hackett, 1982. Print.

Stanton, Domna C., ed. The Female Autograph: Theory and Practice of Autobiography from the Tenth to the Twentieth Century. Chicago: U of Chicago $P, 1987$. Print.

Tamboukou, Maria. “Becomings: Narrative Entanglements and Microsociology." Forum: Qualitative Social Research 16.1 (2015): 1-18. Institute for Qualitative Research. Web. 3 Feb. 2018.

—. "Beyond Figuration and Narration: Deleuzian Approaches to Gwen John's Paintings." Deleuze Studies 8.2 (2014): $230-55$.

—. "In the Fold Between Life and Art." Mariatamboukoupersonalblog, n.d. Web. 8 Feb. 2018.

—. "Narrative Personae and Visual Signs: Reading Leonard's Intimate Photo-Memoir." a/b: Auto/Biography Studies 29.1 (2014): $27-49$.

-. Nomadic Narratives, Visual Forces: Gwen John's Letters and Paintings. New York: Peter Lang, 2010. Print.

—. "Relational Narratives: Autobiography and the Portrait." Women Studies International Forum 33 (2010): 170-79. Print.

Topali, Maria. "Dream on a Light Blue Background." Tea Set. 1999. Greek Poetry Now!: A Directory for Contemporary Greek Poetry, translated by Alexandra Halkias, www.greekpoetrynow.com/poet_poems_eng/topali_poems.html. Accessed 8 Feb. 2018. 